\title{
INFLUENCE OF LIGHTING MAINTENANCE ON THE ENERGY CONSUMPTION
}

\author{
Ruzena Kralikova, Emil Wessely \& Frantisek Koblasa
}
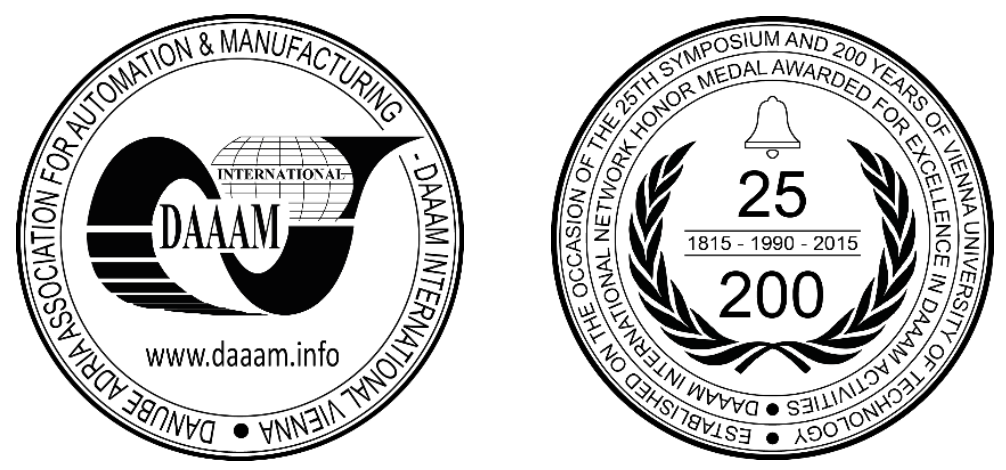

This Publication has to be referred as: Kralikova, R[uzena]; Wessely, E[mil] \& Koblasa, F[rantisek] (2018). Influence of Lighting Maintenance on the Energy Consumption, Proceedings of the 29th DAAAM International Symposium, pp.0109-0118, B. Katalinic (Ed.), Published by DAAAM International, ISBN 978-3-902734-20-4, ISSN 1726-9679, Vienna, Austria

DOI: $10.2507 / 29$ th.daaam.proceedings.015

\begin{abstract}
The improvements in the lighting system maintenance belong to the easiest and most efficient measures of lighting energy saving. Only the entry in the form of thorough and qualified service is required. From the point of maintenance view, the maintenance factors deal with the fact that lighting installations will gradually reduce the amount of light they provide over a number of years, due to lumen depreciation, dirt, failures and so on. The maintenance factor is a percentage of the total light output at the start of the installation life, to which the output may eventually fall. It tells you how much you need to increase the light level at the start, in order to stay above the required level over the lifetime of the installation. Maintenance factors are an important consideration in the planning of lighting installations. The lighting scheme should be designed with an overall maintenance factor calculated for the selected lighting equipment, environment and specified maintenance schedule. The maintenance factors has a great impact on energy efficiency. If we specify too much lighting at the start of a project because of inaccurate maintenance factors, then the user will pay for that heavily through their electricity bills. Most projects of lighting are based on proposals for ensuring uniformity of the intensity of illumination on a horizontal plane of comparison, for observing the recommended ratio of illuminance and brightness between the place of a visual task and its immediate surroundings and of their utilization of light energy sources. Every project is different so the maintenance factor should be altered to suit the circumstances and the lighting technology being used. This paper describes the impact of the lighting maintenance on energy consumption.
\end{abstract}

Keywords: maintenance factor; lighting; illumination; environment; energy

\section{Introduction}

Most projects of lighting are based on proposals for ensuring uniformity of the intensity of illumination on a horizontal plane of comparison, for observing the recommended ratio of illuminance and brightness between the place of a visual task and its immediate surroundings and of their utilization of light energy sources potential [1],[4]. Highgrade and efficient illumination is an effective tool for reducing the cost of the electric power. Savings in consumption of electric power are positively reflected on the quality of the environment. They contribute to reducing of $\mathrm{CO}_{2}$ emissions and of the load of environment by harmful substances arising from the production of electric power from primary sources [2], [10], [11]. 
The good building design characteristic, including both the engineering and non engineering disciplines, might be summarized as follow [3], [12]:

1. Meets the purpose and needs of the building's owners and occupants.

2. Meets the requirements of health, safety and environmental impact as prescribed by codes and recommend by consensus standards.

3. Achieves good indoor environment quality which in turn encompasses high quality in the following dimensions: visual comfort, thermal comfort, indoor air quality, acoustical comfort etc.

4. Creates the intended emotional impact on the building's occupants and beholders.

The efforts to reduce energy consumption are most frequently concentrating on a use of more efficient or more effective lighting systems/HVAC that would meet required technical parameters. From point of illumination it is generally accepted that more effective transfer of electricity into a visible light requires more expensive lamps and related additional investment costs (ballasts, regulation devices, etc.) [14]. As a result, the relation between an acquisition price and a performance is the main obstacle in the effort to convince a user of the installation of energetically more efficient lighting systems. [15]

The energy efficiency of lighting in the practise can be achieved by various ways [13]:

- Replacement of lamps.

- Replacement of luminaires.

- Reconstruction of a lighting system.

- Lighting control.

- Increase in daylight use.

- Change in maintenance system etc.

In order to carry out this study, two different software systems were used: DIALux for the lighting analysis, simulation and visualisation of storehouse; calculations of lighting parameters were carried according to the standard EN 12464-1 and AGi32 software program [20].

\section{Lighting System Maintenance}

The improvements in the lighting system maintenance belong to the easiest and most efficient measures. Only the entry in the form of thorough and qualified service is required [7].

The regular maintenance is very important for the efficiency of the lighting system. Therefore, the maintenance must be carried out in regular intervals. A correctly scheduled maintenance plan helps to maintain the illumination, reduce investment and operational costs and operate the system safely [6].

Every project is different so the maintenance system should be altered to suit the circumstances and the lighting technology being used [21]. The fact is that the influence of maintenance on energy consumption for lighting is not negligible [6].

\subsection{Maintenance Factor}

The maintenance factor is a value by which it is needed to oversize the resulting lighting parameters in a lighting system design in such a way so that when a drop in a luminous flux occurs, it will not result in a drop of these lighting parameters below the values specified in the standards, due to time changes in the operation (ageing of lamps, luminaire material, dirtying) until scheduled maintenance [16].

Maintenance factors deal with the fact that lighting installations will gradually reduce the amount of light they provide over a number of years, due to lumen depreciation, dirt, failures and so on. Maintenance factor (MF) is defined as the "ratio of the average illuminance on the working plane after a certain period of use of a lighting installation to the initial average illuminance obtained under the same conditions for the installation" therefore taking account of all losses including lamp lumen maintenance CIE 97(2005). The MF is a percentage of the total light output at the start of the installation life, to which the output may eventually fall. It tells you how much you need to increase the light level at the start, in order to stay above the required level over the lifetime of the installation. Maintenance factors are an important consideration in the planning of lighting installations. The lighting scheme should be designed with an overall maintenance factor calculated for the selected lighting equipment, environment and specified maintenance schedule.

Every project is different so the maintenance factor should be altered to suit the circumstances and the lighting technology being used. If we consider what the key elements that go into the MF are, then we see a number of factors make up the final figure. The maintenance factor MF is calculated by a product of particular components.

The formula for the overall maintenance factor (MF) for indoor lighting is:

$M F=(L L M F \times L S F) \times L M F \times R M F$ 
Where:

$L L M F$ - lamp lumen maintenance factor

$L S F$ - lamp survival factor

$L M F$ - luminaire maintenance factor

$R M F$ - room maintenance factor

$S M F$ - surface maintenance factor

As this study is primarily concerned with illustrating the energy balance for a lighting system, lamp survival factors (LSF) have been omitted from the calculations. The maintenance factor is influenced immediately, which, however, is of greater importance only if the lighting is controlled to a constant illumination.

If a luminaire and lamp type is known, the maintenance factor influence is to be included in a lighting system design. From the point of maintenance view, the luminaires are categorized by Table 1 .

\begin{tabular}{|c|c|c|}
\hline Categories & Luminaire type & Description \\
\hline $\mathbf{A}$ & Unshaded luminaire & Luminaire with unshaded light source \\
\hline $\mathbf{B}$ & $\begin{array}{l}\text { Open luminaire } \\
\text { without top cover (with } \\
\text { natural ventilation) }\end{array}$ & $\begin{array}{l}\text { Direct-indirect luminaire without cover } \\
\text { Direct-indirect luminaire with indirect reflector and closed optical system } \\
\text { Luminaire for lighting of wall (with vertical outlet opening) } \\
\text { Wall lamp opened up and down } \\
\text { Downlights ceiling luminaire, open at the top }\end{array}$ \\
\hline $\mathbf{C}$ & $\begin{array}{l}\text { Luminaire with the top } \\
\text { cover }\end{array}$ & $\begin{array}{l}\text { The recessed luminaire } \\
\text { Ceiling closely angle luminaire } \\
\text { Downlights spotlight }\end{array}$ \\
\hline $\mathbf{D}$ & Closed luminaire IPX2 & Luminaire for general use with the cover is closed and optical systems \\
\hline $\mathbf{E}$ & $\begin{array}{l}\text { Dustproof luminaire } \\
\text { IPX5 }\end{array}$ & Luminaire, which is protected to dust resistant \\
\hline $\mathbf{F}$ & $\begin{array}{l}\text { Indirect luminaire (up } \\
\text { light) }\end{array}$ & Free-standing, wall-mounted, wall-indirect, closed down \\
\hline G & $\begin{array}{l}\text { Luminaire with } \\
\text { controlled air } \\
\text { conditioning }\end{array}$ & $\begin{array}{l}\text { Luminaire with optic used with the air conditioning or with ventilation } \\
\text { systems }\end{array}$ \\
\hline
\end{tabular}

Table 1. The categories of luminaires according to maintenance [19]

During operation, it is recommended to carry out a regular inspection of the lighting system condition. The categories of cleanliness and recommended intervals of cleaning are specified in Table 2., however, higher legal regulations that may include more strict requirements, are applied to workplaces. Or as the case may be, the cases beyond the given classification may occur.

\begin{tabular}{|l|c|l|}
\hline Category of cleanliness & Interval of check & \multicolumn{1}{c|}{ Workplace } \\
\hline Very clean $($ VC) & 3 years & $\begin{array}{l}\text { Clean rooms, plants for the production of semiconductor, } \\
\text { hospital departments, data centers }\end{array}$ \\
\hline Clean $(\mathbf{C})$ & 3 years & Offices, schools, hospitals areas \\
\hline Normal (N) & 2 years & $\begin{array}{l}\text { Shops, laboratories, restaurants, department stores, } \\
\text { assembly areas, workshops }\end{array}$ \\
\hline Dirty/Soiled (D/S) & 1 year & $\begin{array}{l}\text { Steel mills, chemical plants, foundries, welding, polishing, } \\
\text { woodwork }\end{array}$ \\
\hline
\end{tabular}

Table 2. The categories of cleanliness and recommended intervals of lighting system cleaning [19]

For quick information of workers, who ensure the maintenance plan, the intervals of cleaning of various types of luminaires used in various environments are given in Table 3. The table can also be used for a selection of a luminaire from the point of view of maintenance for a specific environment.

The data are typical for all luminaires and optional lamps, except for high pressure discharge lamps with parameters that are analogous to B-category luminaires. 


\begin{tabular}{|c|c|c|c|c|c|c|c|c|c|}
\hline \multirow{4}{*}{ Type of luminaires } & \multicolumn{9}{|c|}{ Intervals of cleaning } \\
\hline & \multicolumn{3}{|c|}{3 years } & \multicolumn{3}{|c|}{2 years } & \multicolumn{3}{|c|}{1 year } \\
\hline & \multicolumn{9}{|c|}{ Indoor cleanliness } \\
\hline & $\mathrm{VC} / \mathrm{C}$ & $\mathbf{N}$ & $\mathbf{S}$ & $\mathrm{VC} / \mathrm{C}$ & $\mathbf{N}$ & $\mathbf{S}$ & $\mathrm{VC} / \mathrm{C}$ & $\mathbf{N}$ & $\mathbf{S}$ \\
\hline A: Unshaded & $\mathrm{x}$ & & & & $\mathrm{x}$ & & & & $\mathrm{x}$ \\
\hline B: Without top cover & $\mathrm{x}$ & & & & $\mathrm{x}$ & & & & $\mathrm{x}$ \\
\hline C: With top cover & $\mathrm{x}$ & & & $\mathrm{x}$ & & & & $\mathrm{x}$ & \\
\hline D: Closed IPX2 & $\mathrm{x}$ & & & $\mathrm{x}$ & & & & $\mathrm{x}$ & \\
\hline E: Dustproof IP52 & $\mathrm{x}$ & $\mathrm{x}$ & & & & $\mathrm{x}$ & & & \\
\hline F: Indirect closed & & & & $\mathrm{x}$ & & & $\mathrm{x}$ & $\mathrm{x}$ & \\
\hline G: With controlled air conditioning & $\mathrm{x}$ & $\mathrm{x}$ & & & & $\mathrm{x}$ & & & \\
\hline
\end{tabular}

Table 3. The intervals of cleaning ( $\mathrm{x}$ ) of various types of luminaires used in various environments

\subsection{Maintenance Plan}

The obligation of a lighting designer is to prescribe the way and rules of maintenance, since the data and results obtained by light and technical calculation can be applied only under these conditions [5]. If there is a problem how to economically (in terms of investment costs and energy consumption) reach the required photometric parameters at lighting projecting, it is possible to make maintenance intervals more frequent (an increase of maintenance costs) and to increase the value of the maintenance factor.

The plan of maintenance is to include:

- Interval of maintenance execution.

- Description of activities performed within the framework of a regular maintenance.

- Description of activities performed within the framework of extraordinary maintenance (service action).

- Way of luminaires and surfaces cleaning.

Designing the lighting system, individual components, systems and surface finishing can be selected in such a way as to minimize the maintenance demands.

The following is required [4]:

- Selection of the luminaires, where the lamps are enclosed in a dust-tight cover with an appropriate seal, so as to enable the luminaire breathing without a dust penetration.

- Selection of self-cleaning open luminaires, where streams arising from the heat produced by lamps are directed to flow around the reflective surfaces, in order to prevent a dust settlement.

- Application of aerated luminaires, where a forced ventilation is instrumental in dust and dirt removal.

- Recommendation of such optical systems only that are suitable for prevailing environmental conditions, e.g. plastic grids do not fit for dusty premises.

- Reduction of the number of installation options.

- Application of the luminaires with small numbers of components, so as to be easy manipulable or demountable for repair purposes in a workshop if needed.

- Recommendation of the surface finishing that remains clean for long time and is easily cleanable.

Designer-made maintenance plan overview (diagram) example for a building artificial lighting system is shown in Table 4. The example shown is to be regarded as the simplified and illustrative one.

If a luminaire and lamp type is known, the maintenance factor influence is to be included in a lighting system design. The maintenance factor is a value by which it is needed to oversize the resulting lighting parameters in a lighting system design in such a way so that when a drop in a luminous flux occurs, it will not result in a drop of these lighting parameters below the values specified in the standards, due to time changes in the operation (ageing of lamps, luminaire material, dirtying) until scheduled maintenance. [6]

\subsection{Maintenance Factor}

The lighting scheme should be designed with an overall maintenance factor (MF) calculated for the selected lighting equipment, environment and specified maintenance schedule. The MF has a great impact on energy efficiency. The assumptions made in the derivation of the MF shall be optimized in a way that leads to a high value. Guidance on the derivation of MF for artificial lighting systems can be found in CIE 97-2005. [16] 


\begin{tabular}{|l|c|c|c|c|c|c|c|c|c|c|}
\hline Maintenance plan & Y1 & Y2 & Y3 & Y4 & Y5 & Y6 & Y7 & Y8 & Y9 & Y10 \\
\hline Cleaning of Luminaires & $2 \mathrm{x}$ & $2 \mathrm{x}$ & $2 \mathrm{x}$ & $2 \mathrm{x}$ & $2 \mathrm{x}$ & $2 \mathrm{x}$ & $2 \mathrm{x}$ & $2 \mathrm{x}$ & $2 \mathrm{x}$ & $2 \mathrm{x}$ \\
\hline Cleaning surfaces indoor & & & & $1 \mathrm{x}$ & & & & $1 \mathrm{x}$ & & \\
\hline Replacement of Lamp/Luminaires & & & & $1 \mathrm{x}$ & & & & $1 \mathrm{x}$ & & \\
\hline Maintenance plan & $\mathrm{Y11}$ & $\mathrm{Y12}$ & $\mathrm{Y13}$ & $\mathrm{Y14}$ & $\mathrm{Y15}$ & $\mathrm{Y16}$ & $\mathrm{Y17}$ & $\mathrm{Y18}$ & Y19 & Y20 \\
\hline Cleaning of Luminaires & $2 \mathrm{x}$ & $2 \mathrm{x}$ & $2 \mathrm{x}$ & $2 \mathrm{x}$ & $2 \mathrm{x}$ & $2 \mathrm{x}$ & $2 \mathrm{x}$ & $2 \mathrm{x}$ & $2 \mathrm{x}$ & $2 \mathrm{x}$ \\
\hline Cleaning surfaces indoor & & $1 \mathrm{x}$ & & & & $1 \mathrm{x}$ & & & & \\
\hline Replacement of Lamp/Luminaires & & $1 \mathrm{x}$ & & & & $1 \mathrm{x}$ & & & & \\
\hline
\end{tabular}

Table 4. Maintenance plan overview (diagram) / Legend: Y0 - year of lamps installation (date), Y1 -Y20 are year calculated from year of lamp installation, Y20 - lifetime (end of lifecycle lamp)

\section{Case study}

So as to create a synthesis between the analysis of strategies of efficient utilization of electricity for lighting and the capabilities of an intelligent software intended for designing and calculation of the lighting systems a reference model is presented. For options of searching of best maintenance in a working environment demonstration, a fictitious warehouse was created in DIALux software, designated for dispatch, packing and handling goods.

\subsection{Reference Object Selection}

The building of the storehouse is $5880 \mathrm{~m}^{2}$ with a pitched roof (height $12 \mathrm{~m}$ ) having no windows or skylights. The lighting scheme has been designed to meet 200 lux as per BS EN 12464-1: 2011 [17] with 0.6 uniformity (Uo) for the task area and 0.4 uniformity for the surrounding areas. Industry standard reflectances have been used for the building: 0.70 for the ceiling and roof structure; 0.5 for the grey breeze block walls and 0.2 for the unpolished concrete floor. All luminaires are mounted at $12 \mathrm{~m}$ (height measured from the bottom of the fitting) and are suspended from the roof structure. The working plane is calculated at floor level $(0 \mathrm{~m})$ to represent the type of activities taking place in the warehouse. The conditions inside the building are assumed to be a normal environment of storehouse. All illuminance calculations were carried out using AGi32 software program [20].

The basic parameters of the shop are given in Table 5. Production industrial shops that are commonly used today, utilize the daylight intake to the small extent only. Daylight intake to these objects is, in most cases, ensured by side lighting openings in the shop cladding, or by skylights in a ceiling structure [8]. There are also the cases, where the daylight intake is completely missing. All calculations connected with the reference shop lighting system proposals were carried out provided that daylight influence is excluded, i.e. the proposals only consider artificial lighting. For the need of the determination of energy consumption of proposed lighting systems, the annual operation time must be specified. The calculations considered a two-shift operation and 5 working days in a week. Table 6 shows the annual operation time of the reference store lighting system. The proposals relate to the reference warehouse main lighting.

\begin{tabular}{|c|c|c|c|}
\hline \multirow{2}{*}{ Dimensions room } & Length & Width & Height \\
\hline & $98 \mathrm{~m}$ & $60 \mathrm{~m}$ & $12 \mathrm{~m}$ \\
\hline \multirow{2}{*}{ Methods of maintenance plan } & \multicolumn{2}{|c|}{ Ambient conditions } & Maintenance interval \\
\hline & \multicolumn{2}{|c|}{ Soiled } & Early \\
\hline \multirow{3}{*}{ Surfaces of room } & \multicolumn{3}{|c|}{ Degree of reflection } \\
\hline & The ceiling & The walls & The floor \\
\hline & $70 \%$ & $50 \%$ & $20 \%$ \\
\hline
\end{tabular}

Table 5. The basic input lighting environment parameters of the shop

\begin{tabular}{|c|c|c|c|c|}
\hline $\begin{array}{c}\text { The number of } \\
\text { working days per } \\
\text { year }\end{array}$ & $\begin{array}{c}\text { Changes / working } \\
\text { hours }\end{array}$ & $\begin{array}{c}\text { Use lighting } \\
\text { system during } \\
\text { working hours }\end{array}$ & $\begin{array}{c}\text { Daily operating } \\
\text { time of the lighting } \\
\text { system }\end{array}$ & $\begin{array}{c}\text { Annual operating } \\
\text { time lighting } \\
\text { system }\end{array}$ \\
\hline 250 & $2 / 8$ hours & non stop & 16 hours & 4000 hours \\
\hline
\end{tabular}

Table 6. The annual operation time of the reference shop lighting system

The warehouse model is shown on Figure 1. Virtually, there are 2-D and 3-D projections of a false colour rendering, where the colour scale changes on the basis of a change in the illumination or brightness. In the literature, it is also called a planar map of isophotic surface (for 2D projection) and a spatial map (for 3D projection) shows Figure2. 


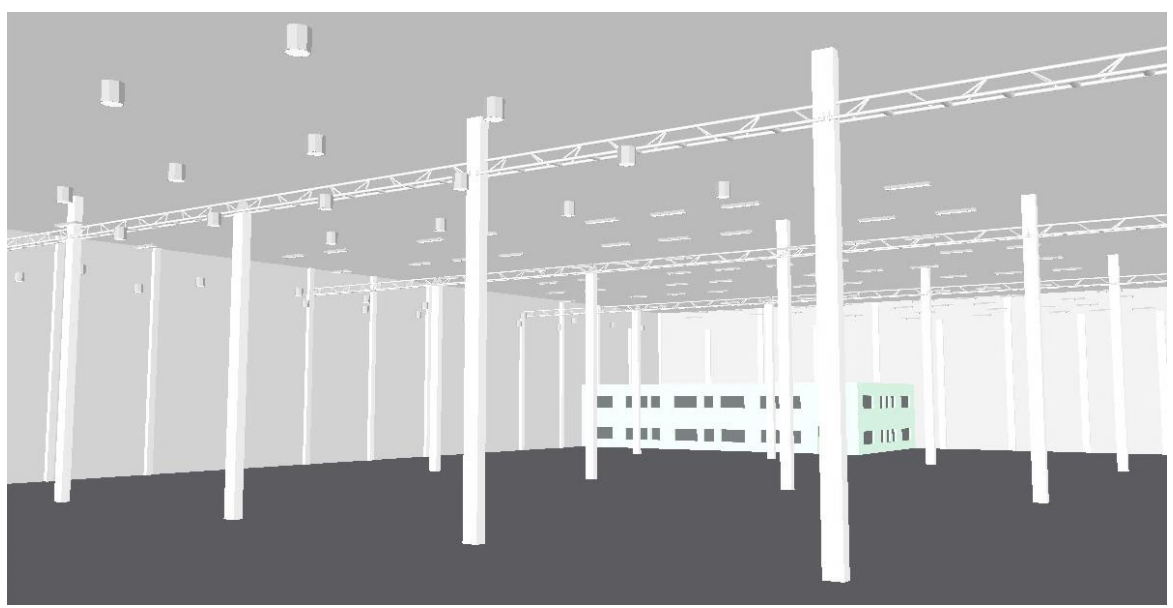

Fig. 1. Model of the reference warehouse - example

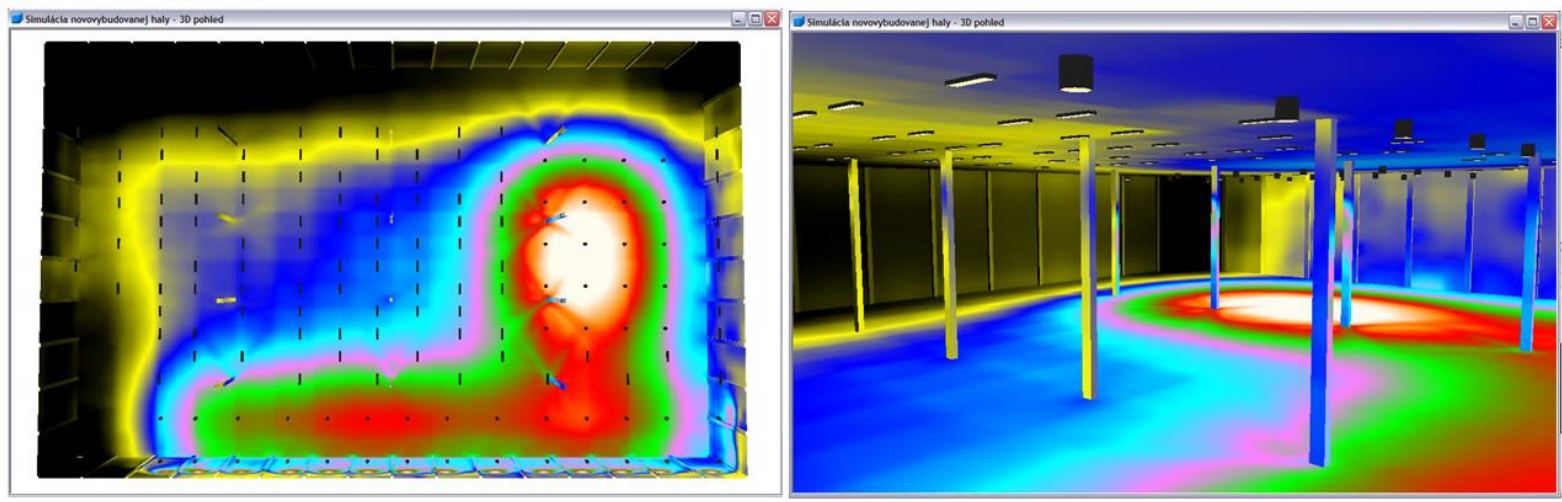

Fig. 2. False colour rendering in Dialux software

For the reference warehouse, the values prescribed by STN EN 12 464-1, are given in Table 7 [17]. The average illuminance must not fall under the values given in the table, regardless of the age and condition of the lighting system.

Based on parameters given in Table7, the lamps with colour rendering index of $R a \geq 60$ were selected for the lighting system designs. A lamp light colour was chosen within the range of warm white and white colours, with the colour temperature value TC ranging from $2150 \mathrm{~K}$ to $4000 \mathrm{~K}$. All considered lamps used for lighting system proposals fulfil the quality requirements for lighting for the given type of activity performed. In the initial calculation of lighting system was use level illuminance $\overline{\mathrm{E}}_{\mathrm{m}}=200 \mathrm{~lx}$ for entire reference warehouse with a uniform distribution of luminaires. A luminaire lighting point height is $12 \mathrm{~m}$ above the floor for all luminaires.

\begin{tabular}{|c|c|c|c|c|}
\hline Type of room, task or activity & $\overline{\mathbf{E}}_{\mathbf{m}}[\mathbf{l x}]$ & UGR $_{\mathbf{L}}[-]$ & $\mathbf{R}_{\mathbf{a}}[-]$ & Remark \\
\hline Dispatch, packing, handling & 100 & 22 & 60 & - \\
\hline Reading, marking, checking & 200 & 19 & 60 & - \\
\hline
\end{tabular}

Table 7. The requirements for illuminance at the point of visual tasks [9]

\subsection{Determination of a Maintenance Factor for the Reference Shop}

The determination of the maintenance factor for the reference shop lighting system is based on following presumptions:

- Annual operation time of the system $-4000 \mathrm{~h}$.

- Quadrennial replacement of the luminaires - 16000 hours of lighting.

- Luminaire maintenance interval - annually.

- Luminaire categorization from the point of view of maintenance $-\mathrm{E}-$ a dustproof luminaire.

- Workplace cleanliness category - dirty/fouled (D/F).

- Distribution of luminous flux - direct.

- Room surface reflectivity $-0.70 / 0.50 / 0.20$.

The reference shop maintenance factor under abovementioned conditions is specified in Table 8 according equation (1). 


\begin{tabular}{|l|c|}
\hline Factor lumen lamps (LLMF) & 0.82 \\
\hline Factor survival reliability lamps (LSF) & 0.80 \\
\hline Factor lumen luminaire pollution impacts (LMF) & 0.86 \\
\hline Factor contamination of the surface temperature (RSMF) & 0.86 \\
\hline \multicolumn{1}{|c|}{ The total lumen maintenance (MF) } & MF =0.82 $\times 0.86 \times 0.86=\mathbf{0 . 4 9}$ \\
\hline
\end{tabular}

Table 8. The reference shop maintenance factor

While designing the lighting systems, it is important to take a value of the maintenance factor into account, in order a reference plane illumination not to fall below the lowest permitted values of the maintained illuminance $\overline{\mathrm{E}}_{\mathrm{m}}$ at the time of a scheduled maintenance.

\subsection{Determination of Efficient Maintenance Schedule for Reference Shop}

Based on assumptions determined for the reference shop, the reference shop maintenance factor was calculated as $\mathrm{MF}=0,61$, and as such, it requires a considerable oversizing of the lighting system, what, in the upshot, will have the impact on its total energy consumption. By this reason, a maintenance plan is elaborated so as to increase the overall value of the maintenance factor. To elaborate an efficient maintenance schedule, it is needed to take into account data specified in Table 9.

\begin{tabular}{|c|c|c|}
\hline Category lamp / lamp type & E/ dustproof lamp & Luminaire protected against dust \\
\hline Category cleanliness/control interval & contaminated $(\mathrm{Z})$ / 1 year & $\begin{array}{l}\text { steel mills, chemical plants, foundries, } \\
\text { welding, polishing, working with wood }\end{array}$ \\
\hline Interval relamping & 3 years $(12000 \mathrm{~h})$ & LLMF $=0.90$ \\
\hline Cleaning interval & $2 \mathrm{x}$ yearly & $\mathrm{LMF}=0.91$ \\
\hline Factor of mortality lamp & individual exchange sources & $\mathrm{LSF}=1$ \\
\hline Interval surface cleaning rooms & $2 \mathrm{x}$ yearly & \multirow{2}{*}{$\mathrm{RSMF}=0.92$} \\
\hline Surface reflectance & $0.70 / 0.30 / 0.20$ & \\
\hline \multicolumn{2}{|c|}{ The total lumen maintenance } & $\mathrm{MF}=0.75$ \\
\hline
\end{tabular}

Table 9. Conditions for streamlining the maintenance schedule and increases the maintenance factor

In Table 10, an overview of the maintenance schedule (a cyclograph) for an artificial lighting system in a reference engineering shop is shown, where Y0 - year (date) installation of the lightings, $\mathrm{Y} 1-\mathrm{Y} 20$ - one year from year of installation, Y20 - year nominal lifetime achievement lamps.

\begin{tabular}{|l|c|c|c|c|c|c|c|c|c|c|}
\hline Maintenance plan & Y1 & Y2 & Y3 & Y4 & Y5 & Y6 & Y7 & Y8 & Y9 & Y10 \\
\hline Cleaning of Luminaires & $2 \mathrm{x}$ & $2 \mathrm{x}$ & $2 \mathrm{x}$ & $2 \mathrm{x}$ & $2 \mathrm{x}$ & $2 \mathrm{x}$ & $2 \mathrm{x}$ & $2 \mathrm{x}$ & $2 \mathrm{x}$ & $2 \mathrm{x}$ \\
\hline Cleaning surfaces indoor & $2 \mathrm{x}$ & $2 \mathrm{x}$ & $2 \mathrm{x}$ & $2 \mathrm{x}$ & $2 \mathrm{x}$ & $2 \mathrm{x}$ & $2 \mathrm{x}$ & $2 \mathrm{x}$ & $2 \mathrm{x}$ & $2 \mathrm{x}$ \\
\hline Replacement of Lamp /Relamping & & & $1 \mathrm{x}$ & & & $1 \mathrm{x}$ & & & $1 \mathrm{x}$ & \\
\hline Maintenance plan & $\mathrm{Y11}$ & $\mathrm{Y12}$ & $\mathbf{Y 1 3}$ & $\mathrm{Y14}$ & $\mathrm{Y15}$ & $\mathbf{Y 1 6}$ & $\mathrm{Y17}$ & Y18 & Y19 & Y20 \\
\hline Cleaning of Luminaires & $2 \mathrm{x}$ & $2 \mathrm{x}$ & $2 \mathrm{x}$ & $2 \mathrm{x}$ & $2 \mathrm{x}$ & $2 \mathrm{x}$ & $2 \mathrm{x}$ & $2 \mathrm{x}$ & $2 \mathrm{x}$ & $2 \mathrm{x}$ \\
\hline Cleaning surfaces indoor & $2 \mathrm{x}$ & $2 \mathrm{x}$ & $2 \mathrm{x}$ & $2 \mathrm{x}$ & $2 \mathrm{x}$ & $2 \mathrm{x}$ & $2 \mathrm{x}$ & $2 \mathrm{x}$ & $2 \mathrm{x}$ & $2 \mathrm{x}$ \\
\hline Replacement of Lamp /Relamping & & $1 \mathrm{x}$ & & & $1 \mathrm{x}$ & & & $1 \mathrm{x}$ & & \\
\hline
\end{tabular}

Table 10. Overview of the maintenance plan (graph) for the reference buildings

In general, the MF is a reduction factor, used in calculation the final illuminance $E m$ that will be experienced at the end of life of the lighting installation. It reduces the calculated initial value $E i$ of the illuminance:

$$
E m=M F \times E i
$$

Where: $E m$ - maintained illuminance value according to the norm [17] and $E i$ - initial illuminance value.

Analogically, according to equation (2) and the procedure given in the example of references storehouse, the requirement value of an average maintained illuminance $E m=200 \mathrm{~lx}$, to which the given system is to be designed so as to meet the requirements prescribed in legislation till the time of replacement of luminaires come. 
The calculation proved that it is necessary to design the lighting system to the average initial illuminance value of $E i=$ $267 \mathrm{~lx}$ so as to obtain the maintenance factor $M F=0.75$. This value is, compared with the average illuminance value specified for the initial maintenance schedule and the maintenance factor $M F=0.49$ lower by $141 \mathrm{~lx} \quad(E i=408 \mathrm{~lx})$.

\subsection{Comparison of Lighting System Projects Considering the Maintenance Factor Value}

The influence of the maintenance factor has a considerable impact on a lighting system design and energy consumption. In Table 11, the reference hall lighting system parameters are compared where the uniform parameters were maintained in all designs. The only variable was the system maintenance factor value.

\begin{tabular}{|l|c|c|c|c|c|}
\hline \multirow{2}{*}{\multicolumn{1}{|c|}{ Parameters }} & \multicolumn{5}{c|}{ Maintenance factor MF } \\
\cline { 2 - 6 } & $\mathbf{0 . 4 9}$ & $\mathbf{0 . 7 1}$ & $\mathbf{0 . 7 5}$ & $\mathbf{0 . 8}$ & $\mathbf{0 . 9}$ \\
\hline The number of lamps [pcs] & 85 & 59 & 54 & 52 & 44 \\
\hline Total luminous flux [1m] & 4042899 & 2806248 & 2277054 & 22473303 & 2092795 \\
\hline Total power [W] & 36805 & 25547 & 23382 & 22516 & 19052 \\
\hline Specific input [w/m $\left.{ }^{2}\right]$ & 6.09 & 4.23 & 3.91 & 3.72 & 3.15 \\
\hline Specific input [Wm-2/100 lx] & 1.71 & 1.17 & 1.12 & 1.10 & 0.99 \\
\hline Maintained illuminance $[1 \mathrm{x}]$ & 356 & 361 & 338 & 330 & 319 \\
\hline Uniform illumination [-] & 0.42 & 0.45 & 0.39 & 0.37 & 0.25 \\
\hline${ }^{1)}$ Total power consumption system $[\mathrm{W}]$ & 44166 & 30656.4 & 28192.5 & 27019.2 & 22862.4 \\
\hline Total energy consumption per year $[\mathrm{kWh}]$ & 176664 & 122625.6 & 110765.2 & 108076.8 & 91449.6 \\
\hline${ }^{2)}$ Energy savings per year [kWh] & 0 & 54038.4 & 60821.3 & 68587.2 & 85214.4 \\
\hline${ }^{2)}$ Energy savings per year [\%] & 0 & 31 & 36 & 39 & 48 \\
\hline
\end{tabular}

Table 11. Comparison of Lighting System energy saving depending on MF

${ }^{1)}$ When calculating the total power consumption of lighting equipment to take into account the consumption of (i.e. loss) Protective parts of the light source $(+20 \%)$, the period of use lighting system per year $=4000$ hour

2 ) Calculated on the consumption of energy consumption, the system operator within the comparison $(M F=0.49)$

The graphic comparison of the lighting system energy consumption in $\mathrm{kWh}$ per year, that depends on a change in the maintenance factor $(\mathrm{MF})$ value is shown on Figure 3.

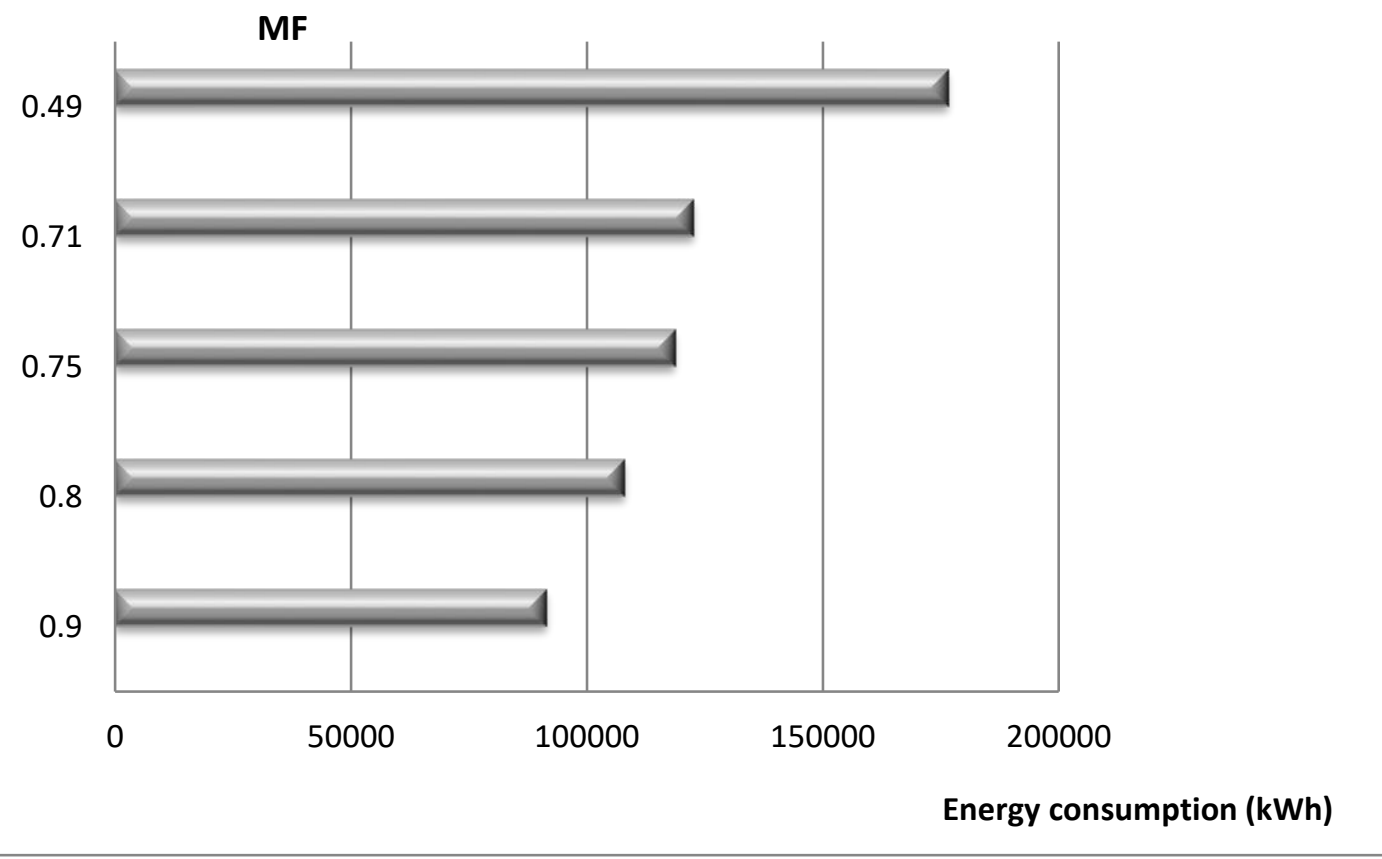

Fig. 3. The graphic comparison the energy consumption that depends on a change in the MF 


\section{Conclusion and discussion}

When designing, in addition to a proper selection of a luminaire and lamp, it is important to take into account the lighting system maintenance schedule which influence the maintenance factor value to a considerable extent. Low values of the maintenance factor result in a considerable overdimensioning of the lighting systems, what is an undesirable condition in the designing of systems with low energy demand. Users are often to be suspicious of high maintenance factor figures. But just because it's higher, doesn't make it wrong. The MF has a great impact on energy efficiency. If we specify too much lighting at the start of a project because of inaccurate maintenance factors, then the client will pay for that heavily through their electricity bills. Although 0.8 is a useful rule of thumb, it's an arbitrary figure, and there is no reason why it should be used on every lighting installation project. Every project is different so the maintenance factor should be altered to suit the circumstances and the lighting technology being used. Thus, if the required light level over the lifetime of the project is $\mathrm{E}_{\mathrm{m}}=500 \mathrm{~lx}$, and the maintenance factor is set at $0.8(80 \%)$, then in order to maintain lighting at the level required, an initial $E_{i}=6251 x$ should be installed to the space. Designers should move away from applying 0.8 universally and treat each project as a one-off and unique [18]. For future research and practise here are issues every lighting professional needs to know about maintenance factors:

- Maintenance factors are recognised as crucial by the industry.

- Pollution levels for the luminaire and space - dust and dirt will affect the quality lighting.

- Service life is key to the calculation in terms of energy use and cos.t

- Having an accurate LLMF in order to find the correct maintenance factor for a lighting project has other benefits in terms of planning and energy saving.

Designers at the early stages of a project, whether new-build or refurbishment, often work without all the information and some intelligent approximations are to be expected based on their professional experiences. However, the best outputs can be realised with a standardised method for verifying LLMF and LSF available, and also guidance on how to compare these directly.

\section{Acknowledgments}

The research in this paper was supported by national grant KEGA No 045TUKE-4/2018 "Transfer of the latest findings of research into processing textbook: Environmental aspects of design engineering objects Ecodesign" supported by Slovak Research and Development Agency and project SGS 21130 "Research and development in the field of 3D technology, manufacturing systems and automation" with the support of the Specific University Research Grant, as provided by the Ministry of Education, Youth and Sports of the Czech Republic in the year 2018.

\section{References}

[1] Boyce, P.R. (2004) Lighting research for interiors: The beginning of the end or the end of the beginning, Lighting Research and Technology, 36 (4), pp. 283-294.

[2] Crnokic, B.; Ljesic, G.; Stojkic, Z. \& Bandic Glavas, M. (2017). Analysis of Energy Consumption in the Building as the Basis for Development of the Modular Model Predictive Control System, Proceedings of the 28th DAAAM International Symposium, pp.0299-0308, B. Katalinic (Ed.), Published by by DAAAM International, ISBN 978-3902734-11-2, ISSN 1726-9679, Vienna, Austria, DOI: 10.2507/28th.daaam.proceedings.041

[3] Civic, A. \& Vucijak, B. (2014) Multi-criteria optimization of insulation options for warmth of buildings to increase energy efficiency, Procedia Engineering, vol. 69, pp. 911- 920. DOI: 10.1016/j.proeng.2014.03.070

[4] Dubois C. et al.(2015) Retrofitting the electric lighting and daylighting systems to reduce energy use in buildings: A literature review, Energy Res. J., vol. 6, pp. 25-41, 2015

[5] Gołębski, R. (2016) Parametric programming of CNC machine tools. MATEC Web Conf. Vol. 94,10 p. DOI:org/10.1051/matecconf/20179407004

[6] Gueorgiev, V. (2018) Specifying Optimal Maintenance Factor in Internal Lighting Applications. In: Abraham A., Abraham A. et al. (eds.), Proceedings of the Second International Scientific Conference "Intelligent Information Technologies for Industry", Advances in Intelligent Systems and Computing. vol. 679, pp.370-378. DOI 10.1007/978-3-319-68321-8_38

[7] Kralikova, R.; Andrejiova, M. \& Wessely, E. (2015) Energy saving techniques and strategies for illumination in industr, Procedia Engineering, vol.100 (January), pp. 187-195. DOI: 10.1016/j.proeng.2015.01.357

[8] Kowalik, M., Rucki, M., Paszta, P. \& Gołębski, R.(2016) Plastic deformations of measured object surface in contact with undeformable surface of measuring tool, Measurement Science Review, vol. 16, no. 5, pp. 254-259.

[9] Leppiman, A.; Kotka, T.; Kõrbe Kaare, K. \& Koppel, O. (2015) Decision-making framework for industrial-size datacenters. Proceedings of the International Conference of DAAAM Baltic "Industrial Engineering", 2015January, pp. 237-242. ISBN: 978-151082263-4

[10] Micieta, V. (2015) Sustainable concept for green logistics and energy efficiency in manufacturing DAAAM International Scientific Book 2015. Chapter 33, pp. 391-400 
[11] Micieta, B.; Zavodska, L.; Rakyta, M. \& Binasova, V. (2015). Sustainable Concept for Green Logistics and Energy Efficiency in Manufacturing, Chapter 33 in DAAAM International Scientific Book 2015, pp.391-400, B. Katalinic (Ed.), Published by DAAAM International, ISBN 978-3-902734-05-1, ISSN 1726-9687, Vienna, Austria DOI: $10.2507 /$ daaam.scibook.2015.33

[12] Palcic, I. \& Buchmeister, B. (2016). Energy Efficiency in Slovenian Manufacturing Industry, Chapter 02. DAAAM International Scientific Book 2016, pp.011-024, B. Katalinic (Ed.), Published by DAAAM International, ISBN 978-3-902734-09-9, ISSN 1726-9687,Vienna, Austria

13] Pellegrino, A.; Lo Verso L. V. R.; Blaso M.; Acquaviva, A. ; Patti, E. \& Osello, A. (2015) Lighting control and monitoring for energy efficiency: A case study focused on the interoperability of building management systems. IEEE 15th Int. Conf. Environ. Elect. Eng. (EEEIC), pp. 748-753.

[14] Petek, J.; Glavič, P. \& Kostevšek, A. (2016) Comprehensive approach to increase energy efficiency based on versatile industrial practices, Journal of Cleaner Production, vol. 112, pp. 2813-2821.

[15] Perlova. E.; Platonova. M.; Gorshkov. A. \& Rakova. X. (2015): Concept Project of Zero Energy Building, Procedia Engineering 100 pp. 1505 - 1514.

[16] CIE 097:2005 Maintenance of indoor electric lighting systems

[17] EN12464-1 "Lighting of work places - Part 1: Indoor work places"

[18] http://www.cibse.org. Peter, T.: Lighting Design - Why Maintenance Factors Matter. Accessed 2018-05-15

[19] https://www.zumtobel.com/PDB/teaser/EN/Maintenance.pdf Accessed on: 2017-06- 13

[20] https://lightinganalysts.com/software-products/agi32/overview/. Lighting Analysts. Accessed on: 2017-06-13

[21] http://luxreview.com/article/2015/08/the-lux-guide-to-maintenance-factors. Accessed on: 2018-01-17 